\title{
Patrick Pillai
}

Yearning to Belong: Malaysia's Indian Muslims, Chitties, Portuguese Eurasians,

Peranakan Chinese, and Baweanese. Singapore: Institute of Southeast Asian

Studies, 2015, xxiii + $25^{8}$ pp. IS BN 9769814519670, price: SGD 39.9o (paperback).

Malaysian society and politics have long been framed by race and broad racial categories. These ideologies underpinning the British colonial system created in the peninsula have continued to anchor the ideologies and policies of nation-building. In this way, the CMIO (Chinese-Malay-Indian-Others) categorization and the bumiputera politics have impacted on the everyday lives of Malaysians and their perceptions of self, community, and society. Yet, the seeming iron cage of CMIO and even the question of bumiputera privilege, have, in recent years, been challenged, not only by minority communities, but also by members of bumiputera communities, although the vagaries of electoral politics have necessitated frequent about-turns by political elites, and a return to racial politics and the championing of the majority. Pillai's book emerges from this changing public sphere and increased questioning of older categories and national precepts over the last two decades.

Yearning to Belong is a comparative study of selected minorities in Malaysia. They are chosen in a way that questions the older categories of Chinese, Malay, Indian, and Others, emphasizing not only the diversity within each category, but also their mixing across categories. Each chapter studies how the different groups, from Indian Muslims, to Chitties, Trengganu Chinese Peranakan, and Baweanese negotiate the cosmopolitan and multicultural environments in Malaysia, their straddling of different cultures and identities in the context of the politics of bumiputra and race in the country. The rather different histories of these migrant and mestizo communities, and their culture, economic positions (class), and living environments, led to different strategies and possibilities for actors and communities within the national identity framework and political economy, regarding acculturation, assimilation, and engagement. Pillai uses both secondary literature for the history of these different communities, and oral history interviews for the contemporary situations and recent developments over the last few decades, although his analysis relies primarily on the latter, which he appends to each chapter.

In the case of the Indian Muslims, the long history of contact with the peninsula, and the association of Islam with Malay ethnicity in colonial Malaya and post-colonial Malaysia, has led to what he called a "dilemma" or "crisis" of identities, as some Indian Muslims have opted to identify themselves as Malay, while others have retained their identities as Indians, although these choices often depended as much on the perceptions and policies of the dominant

(C) KOH KENG WE, 2018 | DOI: 10.1163/22134379-17401016

This is an open access article distributed under the terms of the prevailing CC-BY-NC license 
majority and the state. They adopted a range of strategies to resolve these dilemmas, from the adopting of multiple identities, the formation of political associations and participation in state politics, to marriage, with increasing tendencies to identify themselves more with the Malay community.

The Chitties of Melaka, or Hindu Indian Peranakans, present another a rather different story of acculturation, hybridization, and negotiation. While there were many marriages between cousins within the Chitty community, there seemed to have been a significant trend towards marrying outside the community, with Indians, Chinese, and other ethnic communities. Chitty culture, through intermarriages and the local Malay world environment, became increasingly hybrid, from the architectural style of their homes to their food, dress, language, and performing arts, with the Peranakan Chinese of Melaka playing an important role as what Pillai calls "cultural intermediaries" in some of these processes. He focuses on the spatial environment of Kampong Chitty as the anchor and embodiment of this Chitty identity through the houses and the temples. The threats to this ethnic space has led to attempts to secure bumiputera status for the community, at a time when other non-Muslim Malaysian communities were being granted such status.

This "quest for bumiputera status" can also be seen among the Portuguese Eurasians of Melaka. Like the case of the Chitties, Pillai focuses on the inhabitants in the Portuguese Settlement, outside Melaka town. Like the Chitties, the Portuguese Eurasian culture has become increasingly diverse and mixed, through interaction, acculturation and intermarriage with different ethnic communities. Religion, too, played an important role in identity maintenance over time. Likewise, the challenge to their settlement in the face of land acquisition for development, has led to various strategies, from the linking of the community to place, and the pushing for the recognition of the Portuguese Eurasian community as bumiputera.

Pillai's discussion of the Chinese Peranakans of Trengganu shifts the focus from the western coast of the peninsula to the less-studied east. While there is acculturation to the Malay cultural environment, in the form of dress, language, and architecture, there has been relatively little assimilation, except for some Chinese Peranakans becoming Malay through conversion after marriage. Religion played an important role in identity-maintenance, along with increasing appeal of Mandarin-medium primary schools. Identifying key spaces within the state of Chinese Peranakan community formation, Pillai also noticed how these populations traversed rural settlements and certain urban contexts in Trengganu, such as Kampong Tirok.

The final case study examines the Baweanese, who among all the abovementioned communities were the closest culturally to the Malay community. 
Economic factors had played important roles in stimulating Baweanese migration to the Malay world region (including Riau, Sumatra, Borneo, and the peninsula), with religion also playing an important dimension. While there were cultural differences, and various communities in the peninsula retained their Baweanese identity, intermarriage, education, and state bumiputra policies saw a growing assimilation to Malay identity, especially among second generation migrants.

Ultimately, as his conclusion and introduction shows, Pillai's book is not just an academic exercise, but broader effort to transcend the existing racial politics in Malaysia. Emphasizing hybridity and mixing, as evidenced by these communities, reflects the need to "embrace diversity through more inclusive policies" (p. 208); and this, as Professor Shad Saleem Faruqi puts it in the appendix, may pave the way towards a "shared Malaysian Destiny".

Koh Keng We

Nanyang Technological University

kohkw@ntu.edu.sg 